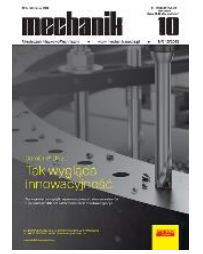

\author{
How to cite this article: \\ Authors: Wojciech Borkowski, Paweł Piórkowski, Wacław Skoczyński, Marek Piórkowski, Andrzej Roszkowski \\ Title of article: "Assessment of cutting machine energy consumption on the example of the VF-7/50 vertical milling \\ center \\ Mechanik, No. 10 (2019) \\ DOI: https://doi.org/10.17814/mechanik.2019.10.79
}

\title{
Assessment of cutting machine energy consumption on the example of the VF-7/50 vertical milling center
}

\author{
WOJCIECH BORKOWSKI \\ PAWEŁ PIÓRKOWSKI \\ WACŁAW SKOCZYŃSKI \\ MAREK PIÓRKOWSKI \\ ANDRZEJ ROSZKOWSKI *
}

* Mgr inż. Wojciech Borkowski, wojciech.borkowski@pwr.edu.pl, https://orcid.org/0000-0001-5906-0874 - Katedra Obrabiarek i Technologii Mechanicznych, Wydział Mechaniczny Politechniki Wrocławskiej, Wrocław, Polska

Mgr inż. Paweł Piórkowski, pawel.piorkowski@pwr.edu.pl, https://orcid.org/0000-0002-7880-0222 - Katedra Obrabiarek i Technologii Mechanicznych, Wydział Mechaniczny Politechniki Wrocławskiej, Wrocław, Polska

Dr hab. inż. Wacław Skoczyński, prof. nadzw. PWr, waclaw.skoczynski@pwr.edu.pl, https://orcid.org/0000-0002-7215-7037 - Katedra Obrabiarek i Technologii Mechanicznych, Wydział Mechaniczny Politechniki Wrocławskiej, Wrocław, Polska

Inż. Marek Piórkowski, 213971@student.pwr.edu.pl - Katedra Obrabiarek i Technologii Mechanicznych, Wydział Mechaniczny Politechniki Wrocławskiej, Wrocław, Polska

Dr inż. Andrzej Roszkowski, andrzej.roszkowski@pwr.edu.pl, https://orcid.org/0000-0003-4337-6262 - Katedra Obrabiarek i Technologii Mechanicznych, Wydział Mechaniczny Politechniki Wrocławskiej, Wrocław, Polska

The assessment of the energy intensity of the VF-7/50 vertical milling center is presented. A study was carried out to collect data on the machine's demand for electricity. A dependence was developed on the basis of which the energy intensity of the machine tool can be determined in the milling process. The results were verified experimentally.

KEYWORDS: energy consumption of the milling machine, milling, machine tools

\section{Introduction}

One of the major problems facing the industry today is the need to reduce energy consumption. The source of high demand for electricity in the engineering industry are, among others, machine tools. Caring for the environment requires that the manufacturers of these machines regularly reduce their energy requirements. Therefore, there is a need to monitor the consumption of electricity in machining processes and to forecast this consumption depending on the type of machine and cutting parameters used. This paper attempts to determine this relationship for a vertical milling center VF-7/50 operating in industrial conditions.

\section{Energy consumption of milling processes}

Modern world is facing a big challenge, which is to solve the problem of growing energy demand in a situation of decreasing supply. As it results from fig. 1, the demand for electricity will increase in comparison with the current state by about $50 \%$ by 2050 . This problem cannot be solved solely by developing renewable energy. Actions are needed to reduce the energy consumption of milling machines. Current estimates indicate that in highly developed countries, such as the USA, the consumption of electricity by milling tools accounts for about $1 / 3$ of its total consumption in industry [1]. The energy consumption of milling tools begins to take on similar significance as the issue of machining efficiency or obtaining adequate dimensional and shape accuracy. 


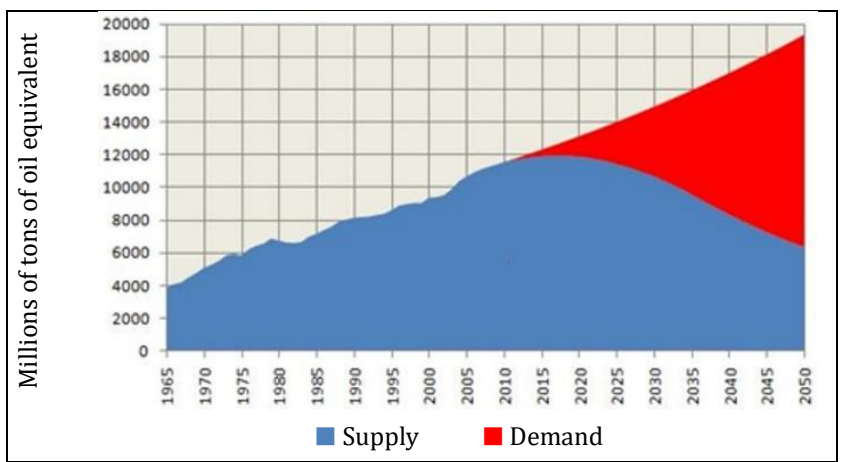

Fig. 1. The difference between supply and demand for energy [1]

There are various concepts of methods that can be used to determine the demand for milling machines for electricity. The work [2] presents an approach based on determining the energy consumption of individual machine elements, such as servos or a tool change system. It allows for a quick estimation of energy consumption in the whole factory. Another concept is the possibility of dividing the total electricity in the machining processes into a component derived from cutting and a component derived from the demand of the machine itself, which is presented in the work [3]. A similar concept was presented in [4].

Based on these concepts, it is possible to create machine tool performance models and make machining strategy decisions based on them [5]. There are models that consider the problem of energy consumption by machine tools much more widely, including such quantities as the amount of energy needed to make milling tools or individual machine components [6]. Most of the energy consumption models currently used, which take into account the energy consumption of individual machine components, are not accurate in cases where different production tasks occur in the production plant [7]. However, there are models that, using multi-criteria analysis, not only allow for estimation of electricity consumption, but also on the basis of available databases, help in making a decision regarding the machining strategy, ensuring production of the workpiece in accordance with the client's requirements and using the least amount of electricity [8 ].

There is therefore a machining strategy that is optimal in terms of electricity consumption [9]. To develop it, a detailed analysis of the impact of milling process parameters on the energy consumption of milling machines is necessary [10]. This applies especially to the implementation of new machining strategies and machining of new materials [11].

\section{Research methodology}

The purpose of the research was to determine the formula, with which it will be possible to determine the energy consumption of the vertical milling center VF-7/50 when milling the $\mathrm{C} 45+\mathrm{N}$ steel. Vertical milling center VF-7/50 (fig. 2) allows for cutting with a maximum torque of $460 \mathrm{Nm}$. The maximum spindle speed is $7500 \mathrm{rpm}$.

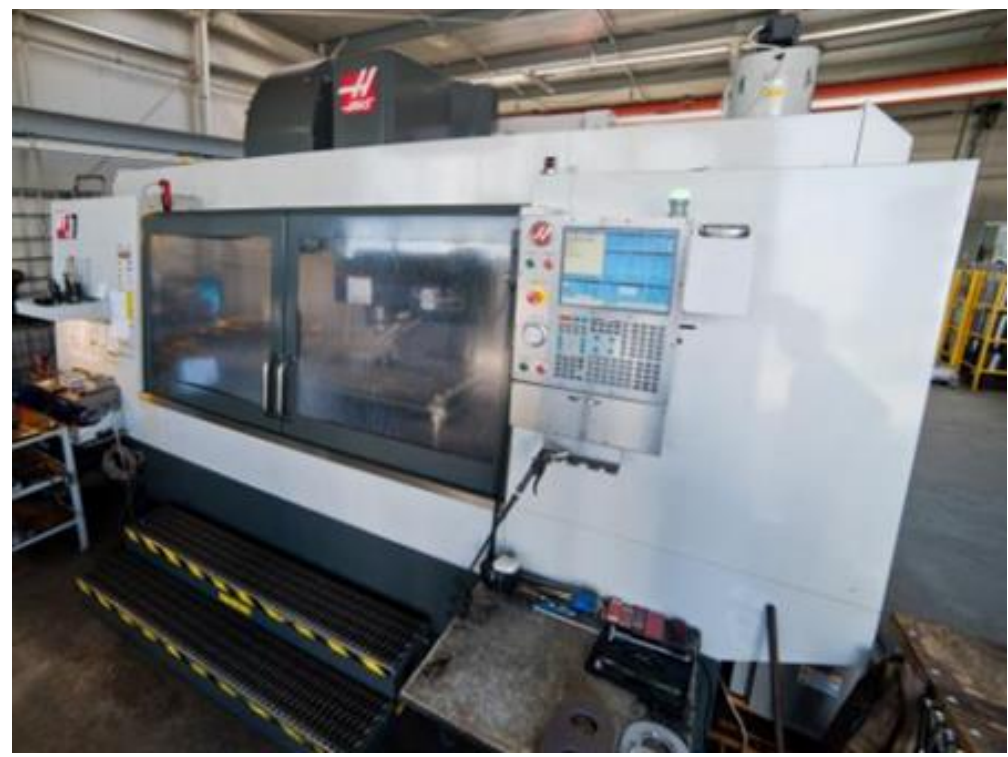

Fig. 2. VF-7/50 vertical milling center 
To achieve the research goal, the Sonel PQM-701 power quality analyzer was connected to the machine (fig. $3)$. The method of data acquisition is described in detail in [12].

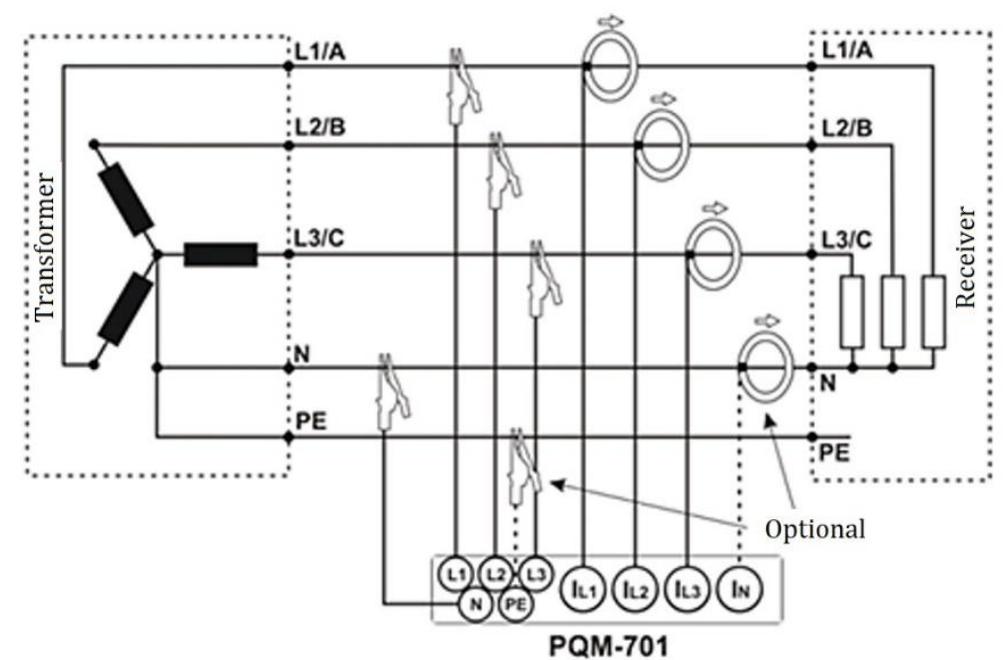

Fig. 3. Connection diagram for the Sonel PQM-701 power quality analyzer to the machine's cables [13]

Using the power quality analyzer, it is possible to determine the amount of electricity that the machine draws at any time during operation. Some of the results recorded on the analyzer were used to develop the formula, and some for its verification.

Three quantities were modified during measurements:

- cutting width (described as the percentage of the milling tool diameter),

- cutting tool diameter,

- cutting speed.

The cutting width varied in the range of $10 \div 100 \%$, the tool diameter $-25 \div 80 \mathrm{~mm}$, and the cutting speed $160 \div 320 \mathrm{~m} / \mathrm{min}$. The $60 \times 120 \times 320 \mathrm{~mm}$ sample was made of $\mathrm{C} 45+\mathrm{N}$ steel. The cutting depth was $3 \mathrm{~mm}$ and the feedrate per tooth was $0.15 \mathrm{~mm} / \mathrm{rev}$.

Sandvik cutting inserts R390-1704.16M-PM 4240 were used for testing. Depending on the diameter of the tool, two, three, five or six inserts were machined. As part of the experiment, many values related to the machine's energy consumption were determined, including the most important one, i.e. the machine's demand for electricity for each of the tests.

In order to determine the relationship between cutting parameters and the machine's electricity demand, the linear regression method was used. A confidence level of 0.99 was established and a very good fit was obtained for the applied linear regression model, for which the coefficient of determination R2 was 0.91 .

The resulting formula had the following form:

$$
E=a \cdot t+V \cdot 0.831617
$$

where: $E$ - machine tool's demand for electricity, $a$ - factor depending on cutting data, $t$ - cutting time, $V$ volume of the cut material.

\section{Verification of energy consumption assessment}

Correctness of the obtained empirical formula was verified for 100 different combinations of cutting parameter, taking into account each of the changed quantities separately as an independent variable. The relative error in individual cases ranged from 0 to $7 \%$ (tab. I). A similar analysis was made for the other two independent variables.

Then the average relative error was determined for each of the changed values considered as independent variables. For cutting speed, the average relative error ranged from 0.0235 to 0.04096 (tab. II). For the tool diameter, the average relative error reached values from 0.02258 to 0.03896 (tab. III). The average relative error for various cutting widths ranged from 0.0097 to 0.04070 (tab. IV). The total average relative error calculated according to the determined empirical formula was only 0.029 and was several times smaller compared to the errors determined from the formulas provided by tool companies. 
TABLE I. Relative error values for individual variants of the tool diameter $d$ and cutting speed $v_{c}$ [14]

\begin{tabular}{|c|c|c|}
\hline$d[\mathrm{~mm}]$ & $V_{\mathrm{c}}[\mathrm{m} / \mathrm{min}]$ & Relative error \\
\hline 25 & 160 & 0.06398 \\
\hline 40 & 160 & 0.04195 \\
\hline 63 & 160 & 0.04308 \\
\hline 80 & 160 & 0.01482 \\
\hline 25 & 200 & 0.01939 \\
\hline 40 & 200 & 0.00161 \\
\hline 63 & 200 & 0.04259 \\
\hline 80 & 200 & 0.06134 \\
\hline 25 & 240 & 0.00342 \\
\hline 40 & 240 & 0.05100 \\
\hline 63 & 240 & 0.04334 \\
\hline 80 & 240 & 0.02332 \\
\hline 25 & 280 & 0.01460 \\
\hline 40 & 280 & 0.00568 \\
\hline 63 & 280 & 0.03899 \\
\hline 80 & 280 & 0.03475 \\
\hline 25 & 320 & 0.01150 \\
\hline 40 & 320 & 0.01436 \\
\hline 63 & 320 & 0.02280 \\
\hline 80 & 320 & 0.05082 \\
\hline
\end{tabular}

TABLE II. Values of average relative error for individual cutting speeds $v_{c}$ [14]

\begin{tabular}{|c|c|}
\hline$v_{\mathrm{c}}[\mathrm{m} / \mathrm{min}]$ & Mean relative error \\
\hline 160 & 0.04096 \\
\hline 200 & 0.03123 \\
\hline 240 & 0.03027 \\
\hline 280 & 0.02350 \\
\hline 320 & 0.02487 \\
\hline
\end{tabular}

TABLE III. The average relative error values for individual tool diameters $d$ [14]

\begin{tabular}{|c|c|}
\hline$d[\mathrm{~mm}]$ & Mean relative error \\
\hline 25 & 0,02258 \\
\hline 40 & 0,02292 \\
\hline 63 & 0,03816 \\
\hline 80 & 0,03701 \\
\hline
\end{tabular}

TABLE IV. Values of average relative error for individual cutting widths $a_{\mathrm{e}}$

\begin{tabular}{|c|c|}
\hline$a_{\mathrm{e}}[\%]$ & Mean relative error \\
\hline 10 & 0,02945 \\
\hline 25 & 0,00970 \\
\hline 50 & 0,01666 \\
\hline 75 & 0,03424 \\
\hline 100 & 0,04070 \\
\hline
\end{tabular}

\section{Summary}

As shown, based on cutting tests, an accurate formula can be developed to describe the relationship between the machine's electricity demand and cutting parameters. On this basis, it is possible to forecast, monitor and, above all, modify the electricity consumption in the production plant. Data obtained during such cutting tests can be used to create databases and expert systems that facilitate machining with lower energy consumption [15].

The absolute error that was obtained during the verification of empirical formula is many times lower than errors determined according to typical dependencies, which can be found in the literature or the instructions 
of the tool manufacturers. However, such a high accuracy of the pattern results from the fact that it was developed for a specific machine and material. As part of further work, the authors plan to expand the scope of research with cutting tests using other materials and other machine tools, as well as to extend the empirical formula with a variable resulting from the cutting resistance of the material (this variable should have a linear effect on the change in the machine's demand for electricity).

Tests using other machines - both numerically controlled milling machines and other cutting machines will allow to determine the impact of machine drive on its demand for electricity.

In the course of research, it was observed that the energy consumption of vertical milling center depended on the gear, in which it worked. After conducting the appropriate cutting test, it will be possible to include this variable in empirical formula, which is important from the point of view of energy consumption.

The empirical formula adds two components of the cutting process - dependent and independent. This division will facilitate a quick and accurate estimation of electricity demand in a large production plant. The research results presented in the paper resulted in establishing the cooperation with one of large production plants in Poland.

\section{REFERENCES}

[1] Seow Y., Rahimifard S. "A framework for modelling energy consumption within manufacturing systems". CIRP Journal of Manufacturing Science and Technology. 4 (2011): 258-264.

[2] Behrendt T., Zein A., Min S. "Development of an energy consumption monitoring procedure for machine tools". CIRP Annals - Manufacturing Technology. 61 (2012): 43-46.

[3] Gutowski T., Dahmus J., Thiriez A. "Electrical energy requirements for manufacturing processes". Proceeding of $13^{\text {th }}$ CIRP International Conference on Life Cycle Engineering, Leuven, Belgium, 31.06.2006: 623-628.

[4] Avram O.I., Xirouchakis P. "Evaluating the use phase energy requirements of a machine tool system". Journal of Cleaner Production. 19 (2011): 699-711.

[5] Rajemi M.F., Mativenga P.T., Aramcharoen A. "Sustainable machining selection of optimum turning conditions based on minimum energy considerations". Journal of Cleaner Production. 18 (2010): 10591065.

[6] Mori M., Fujishima M., Inamasu Y., Oda Y. "A study on energy efficiency improvement for machine tools". CIRP Annals Manufacturing Technology. 60 (2011): 145-148.

[7] Draganescu F., Gheorghe M., Doicin C.V. "Models of machine tool efficiency and specific consumed energy". Journal of Materials Processing Technology. 141 (2013): 9-15.

[8] He Y., Liu B., Zhang X., Gao H., Liu X. "A modeling method of task-oriented energy consumption for machining manufacturing system". Journal of Cleaner Production. 23 (2012): 167-174.

[9] Mouzon G.C., Yildirim M.B. "A framework to minimize total energy consumption and total tardiness on a single machine". International Journal of Sustainable Engineering. 1 (2008): 105-116.

[10] Borkowski W., Skoczyński W., Piórkowski P., Jankowski T., Roszkowski A., Foremniak M. "Influence of parameters of milling process on the energy consumption of machine tool". Advances in Science and Technology Research Journal. 12, 3 (2018): 24-31.

[11] Chudy R., Grzesik W. "Comparison of power and energy consumption for hard turning and burnishing operations of 41Cr4 steel". Journal of Machine Engineering. 15, 4 (2015): 113-120.

[12] Roszkowski A., Skoczyński W., Foremniak M., Piórkowski P., Borkowski W., Jankowski T. "Metoda identyfikacji sygnałów zasilania w badaniach energochłonności obrabiarek". Mechanik. 1 (2019): 38-41.

[13] Analizator jakości zasilania PQM-701. Instrukcja obsługi. 2014: 22.

[14] Piórkowski M. „Metoda oceny energochłonności obrabiarek CNC”. Praca dyplomowa inżynierska. Wrocław, 2018.

[15] Newman S.T., Nassehi A., Imani-Asrai R., Dhokia V. "Energy efficient process planning for CNC machining". CIRP Journal of Manufacturing Science and Technology. 5, 2 (2012): 127-136. 